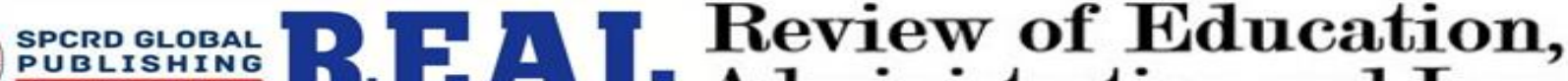

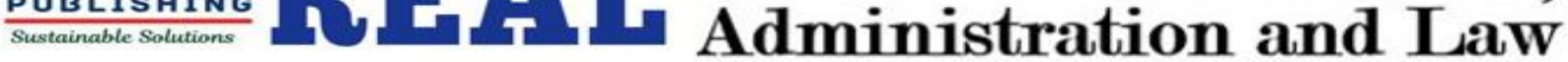

Journal homepage: http://real.spcrd.org ISSN (Print): 2708-1788

ISSN (Online): 2708-3667

\section{"End Up on the Streets": an Evidence-based Study on Street-begging and Poverty in Sialkot, Pakistan}

a Syeda Mahnaz Hassan, ${ }^{\mathrm{b}}$ Nargis Abbas, ${ }^{\mathrm{c}}$ Uzma Aashiq, ${ }^{\mathrm{d}}$ Aniqa Azam

${ }^{a}$ Chairperson, Department of Social Work, University of the Punjab, Lahore, Pakistan

${ }^{\mathrm{b}}$ Assistant Professor, Department of Social Work, University of Sargodha, Sargodha, Pakistan

Email: nargis.abbas@uos.edu.pk

${ }^{\mathrm{c}}$ Assistant Professor, Department of Social Work, University of Sargodha, Sargodha, Pakistan

Email: uzma.ashiq@uos.ed.pk

${ }^{\mathrm{d}}$ PhD Scholar, Department of Social Work, University of the Punjab, Lahore, Pakistan, Pakistan

\begin{tabular}{l}
\hline ARTICLE DETAILS \\
\hline History: \\
Accepted 12 Sep 2020 \\
Available Online 30 Sep 2020 \\
\hline Keywords: \\
Marginalized, Street Beggars, \\
Slums, Urbanization \\
\hline JEL Classification: \\
O18,O19
\end{tabular}

DOI: $10.47067 /$ real.v3i2.74

\begin{abstract}
The rapid development in 21st century not only gave birth to urbanization but also accompanied emergence of slums in cities. Now days, one of the phenomena grabbing serious attention of social scientists is the association between street - begging and poverty not just in developing countries but also in the developed ones. This research paper intends to analyze the relationship that occurs between street begging and poverty as a social issue, leading towards its prevention approaches. The study site was Sialkot, a city of province Punjab, Pakistan. It was descriptive cross - sectional and a quantitative approach in its nature. For primary data collection, descriptive survey and designed questionnaire was administered to One hundred and thirty respondent street - beggars chosen randomly from various public places in city. The data analysis phased employed simple descriptive statistics. Finally, an attempt has been made by recommending in form of a road map in order to prevent the city's discomfort. Findings reveal that majority of beggars are poor, illiterate and needy. They make both ends meet by begging at several spaces and are deprived of generous helping hands. Moreover, begging is a consequence of several factors i.e. poverty, parental loss, physical challenges, unemployment - to name just a few. Furthermore, the recommendations include incorporation of this socio economically marginalized group in Pakistan's anti - poverty program. This section is in dire need of employment opportunities provided by Sialkot's industrialist community in order to desist them from indulging in beggary. The local government authorities and policy planners must embrace multi - targeted approaches in the practice reactive interventions.
\end{abstract}

(C) 2020 The authors. Published by SPCRD Global Publishing. This is an open access article under the Creative Commons AttributionNonCommercial 4.0 


\section{Introduction}

A glance at human life's history that appeals more than anything, is that the evolution of social life and urbanization has been increase ever since begging in its wake so many unresolved social issues to a great extent including panhandling notably (Hamidreza Khazaeifar et al., 2015). The disintegrated village economy is greatly owing to poverty and thousands migrate from rural spaces to cities in search of livelihood creating a situation even worse.

One of the most multifaceted and endemic social problem is beggary but it is seldom understood in its totality (CAMA, 1945). "As a worldwide phenomenon street begging is a significant issue in urban communities among all the republics and more dominant in the developing ones” (Jelili, 2013). Begging is known as a universal phenomenon and it is not peculiar to a specific country. In every urban zone of any country it is a worldwide phenomenon significantly noticeable issue but in the third-world countries it seems to be more pronounced (Tambawal, 2010). In opinion of Ottaway (1975), emergence of "beggary" as a phenomenon took place in relation to private property. In Pakistan, a large segment of populace spend their lives below poverty line.

The subject matter of this research is synonymous with the phenomenon of house - to - house or street begging and poverty. It limits around these problems or associated concepts as "vagrancy" and "panhandling" which describe city beggars. Such a conceptualization would not only reflect socio economic implications based image of beggary question but also capture the state of Sialkot city's marginalized section.

Abdullah, (2001). That is to say, "in virtually every religion of the world issues surrounding alms giving (and by implication begging) are entrenched though with different approaches". In this section the issue of alms giving and begging as obtained in the scriptures of both Islam and Christianity is examined. "Street begging is a nationwide malady that eats into the fabrics of social, economic, religious, political and educational structures” (Eyo, Usoro and Usoro, 2007; cited in Yusuf et al. 2012).

Human society is known as a multifarious entity because of the fact it surrounds people from a number of socio - economic and radical backgrounds with a sequence of activities. Roberts (2001), in "Power and Money, a Social Mirage" advanced that "Since the origin of time, medieval and onto the modern eras, there have been the poor, sick, marginalized, less privileged etc. among others involving in begging and or depending upon the asking for alms for their existence".

According to Murray (2008), "begging is a social action of manipulation by both the donor and the receiver who seek to encourage it as a motivational means for the endurance of such easy going members of a society". In words of Olawale (2007) alms are regarded in form of begging "as the habit of a beggar soliciting for favor from passers - by for survival and enrichment."

Beggary as posited by Daniels (2013), is regarded as one of the “" psychologically damaging and thus worst of life's endeavor is street begging or street pan-handling, which is a usual activity in almost every human civilization." Undeniably begging is dishonorable and degrading activity as maintained by Beatrice (2012), supplementary to that, “it isn't just about emotionally humiliating effects that could be upon a single person, but rather the response of the people to street - beggars".

Three categories of beggars in urban community have been identified by Mason (2011), as those leading sick and disabled parents or kin, vagrants begging entirely at their own dispositions and those acting as 'front for parents,' supervising them from a distance." "For many republics of the third world, 
begging as a sign of miserable poverty, has always been a chief way out for helpless deprived poor" (Adedibu, 2011). Though, not all vagrants are deprived or encouraged into begging by poverty, and not all the deprived are vagrants.

The theory of "Culture of Poverty" highlights that "poverty as a subculture passes from one generation to another and becomes institutionalized in the poor some characteristics which prepares the ground for the phenomenon of begging”. (Demewozu, 2005). Some significant characteristics of poverty include: lower levels of association and lacking volunteerism, social isolation and tendency towards less participation in public actions, lacking professional skills and facing prolong period of unemployment (Anna, 2014).

In societies, where the problems of poor aren't effectively solved and where there's nonavailability of jobs for the skillful people, poverty thrives. Moreover, there are sick mentalities and some values prevailing in the society which propose the poor's lower social status as a consequence of their own inability. In such circumstances, vagrancy is a source of survival and adaptation to the environment. Wilson (2009) suggests that "the phenomenon of street begging at one time or the other and it has lingered over time." Unfortunately, the poor belonging to lower stratum of the society adopt begging to ensure their survival. The poor remain in such a pathetic condition due unemployment, underemployment and notably poverty among others. Hence, there is a constant widening gap between the beggars and elite.

Sometimes religious teachings do not prohibit begging and it proves to be a root cause for promotion of beggary activities. For instance, one among the five pillars in religion Islam is alms giving (Zakat) and from its weightage its value is evident. Thus, Almighty Allah says in Glorious Koran: "And in their properties there was the right of the beggar and the Mahruum (the poor)." It is obvious now, and of course, there is a prohibition upon rejection of beggars in Islam. "And reject not the beggar" (Koran 93, verse 10). Giving alms to the poor is also appreciated in Christianity but vagrancy is silent upon. Thus, declares the Bible: "Whoever gives to the poor will lack nothing. But a course will come upon those who close their eyes to poverty" (Proverbs 28: 27).

As a major social evil beggary issue is prevailing in society with a great extent. The study findings of Ahmadi (2010) represent that "vagrancy is a social issue which has not only psychological consequences such as the development of inferiority complex in the beggars' but also the geographical and social structure of the city zones". According to Foyoh (2013) "now-a-days, poverty and societal changes resulting from urbanization have produced more emotional and persistent social problems, of which begging is the most serious and a visible one". As such, "begging, an almost unnoticed social event and problem, has become the means of occupation for quite a huge number of people".

Coming across beggars anywhere we go is a painful experience. At the railway station, hospital, even at road crossings, market place, even in streets you will find some persons approaching you with 'open palms'. They beg for eatables or money. The chief reasons of beggary are unemployment and poverty. (Frederick, et al., 2016). Hence, there is a constant widening gap between the beggars and elite having socio-economic ramifications making it a serious issue of $21^{\text {st }}$ century. In Pakistan, by the disruption of the joint-family system such a problem is increasing every day. Vagrancy primarily is a symbol of extreme poverty and proves to be an absolute failure at an individual's disposition to sustain resourcefully through specific means of productivity and living.

The efforts to reduce street begging problem have been unsuccessful because governments and 
concerned stakeholders do not have up-to-date information about this issue and its associated factors. Such a lack of in depth understanding has led to attempts that deal with the symptoms of beggary rather than with the root causes of this problem. For filling this information gap, the research study took place in District Sialkot where a large number of beggars beg for alms in public places.

The objectives of this research were to investigate the association between poverty and street begging in Sialkot, Punjab; to detect the consequences and implications that arise due to street begging at large and to recommend the remedial measures for beggary in order to tackle the issue.

\section{Methodology}

Present research study comprised upon exploratory research design and the primary data produced through field survey, carried out during the months of January and February, 2019. The samples consisted of street - beggars in the three selected zones in Sialkot, Punjab. One hundred and fifty (150) beggars of a diverse age group as respondents were randomly selected by convenience sampling method from different parts of the city and were personally interviewed by the researcher for gaining a true picture of their experiences. A self - drafted questionnaire consisting close - ended questions relating to both poverty level and beggary was used as an instrument for data collection purpose.

\subsection{Data Analysis}

After completion of field work process from Sialkot as a unit of study, the collected data was scrutinized and processed in tabular forms conferring many aspects of the research. An analysis of collected data took place with usage of Statistical Package for Social Sciences (SPSS) as the study was quantitative by its very subject. Questionnaire - based coding of responses, analysis and summarizing etc. Use of descriptive statistics for obtaining percentage and frequencies of coded responses proved to be an essential source for the actual results.

The present study gives attention at beggary as an increasing socio-economic issue as an extreme type of poverty and destitution in urban Sialkot. This paper tried to analyze association between poverty and street - begging by focusing on the phenomena of poverty and beggary as dynamic conditions and highly vulnerable situation, embedded in daily urban life. Moreover, the current discourse also explores the likely solutions to deal with 'street - begging' under the existing circumstances.

The following segment presents the particular output from the generated result of the SPSS. It encompasses demographic features of the respondents and the results that are answers of directed questionnaire as well as the related hypotheses proposed early in the research study.

\subsubsection{Demographic distribution regarding percentage of the respondents}

\begin{tabular}{|l|l|c|c|}
\hline Sr.\# & Variables & Frequency & Percentage (\%) \\
\hline I & Beggars' Classes & 18 & $18 \%$ \\
\hline A & Dumb & 07 & $07 \%$ \\
\hline B & Blind & 15 & $15 \%$ \\
\hline C & Deaf & 21 & $21 \%$ \\
\hline D & Leper & 17 & $17 \%$ \\
\hline E & Mentally retarded & 22 & $22 \%$ \\
\hline F & Able Persons Total & 100 & $100 \%$ \\
\hline \multicolumn{2}{|c|}{} \\
\hline
\end{tabular}




\subsubsection{Age-Wise Distribution of Beggars}

\begin{tabular}{|l|c|c|}
\hline $5-6$ years & 09 & $09 \%$ \\
\hline $7-11$ years & 12 & $12 \%$ \\
\hline $12-18$ years & 11 & $11 \%$ \\
\hline $19-25$ years & 27 & $27 \%$ \\
\hline $26-46$ years & 18 & $18 \%$ \\
\hline $47-56$ years & 17 & $17 \%$ \\
\hline 57 years or above & 06 & $06 \%$ \\
\hline Total & 100 & $100 \%$ \\
\hline
\end{tabular}

\subsubsection{Religious Association}

\begin{tabular}{|l|c|c|}
\hline Islam & 87 & $87 \%$ \\
\hline Christianity & 13 & $13 \%$ \\
\hline Total & 100 & $100 \%$ \\
\hline
\end{tabular}

\subsubsection{Sex of Beggars}

\begin{tabular}{|l|l|l|}
\hline Female & 56 & $56 \%$ \\
\hline Male & 44 & $44 \%$ \\
\hline Total & 100 & $100 \%$ \\
\hline
\end{tabular}

Source: Calculated through a sample survey, 2019

\subsubsection{Background Concerning Education}

\begin{tabular}{|l|c|c|}
\hline Illiterate & 83 & $83 \%$ \\
\hline Primary level education & 11 & $11 \%$ \\
\hline $\begin{array}{l}\text { Not completing secondary } \\
\text { level education }\end{array}$ & 06 & $06 \%$ \\
\hline Total & 100 & $100 \%$ \\
\hline
\end{tabular}

\subsubsection{Economic Factors Promoting Poverty and Street - Begging in Sialkot}

\begin{tabular}{|c|l|c|c|}
\hline 1 & Unemployment & 31 & $31 \%$ \\
\hline 2 & Poverty & 44 & $44 \%$ \\
\hline 3 & Insufficient earning & 13 & $13 \%$ \\
\hline 4 & Debt & 07 & $07 \%$ \\
\hline 5 & Lacking employment opportunities & 05 & $05 \%$ \\
\hline & Total & 100 & $100 \%$ \\
\hline
\end{tabular}

\subsubsection{Social Causes Promoting Poverty and Street - Begging in Sialkot}

\begin{tabular}{|c|l|c|c|}
\hline 1 & Orphan hood (both parents died) & 31 & $31 \%$ \\
\hline 2 & Broken family & 08 & $08 \%$ \\
\hline 3 & Old Aged & 19 & $19 \%$ \\
\hline 4 & Lack of caregivers & 18 & $18 \%$ \\
\hline 5 & Influenced by peers/friends & 13 & $13 \%$ \\
\hline 6 & By choice & 11 & $11 \%$ \\
\hline & Total & 100 & $100 \%$ \\
\hline
\end{tabular}

Source: Based upon field survey, 2019 


\subsubsection{Occurrence of Ailments among Street - Beggars in Sialkot City}

\begin{tabular}{|l|l|c|c|}
\hline 1 & Skin Problems & 17 & $17 \%$ \\
\hline 2 & Asthma & 06 & $06 \%$ \\
\hline 3 & Eye Infection & 13 & $13 \%$ \\
\hline 4 & Mental Retardation & 08 & $08 \%$ \\
\hline 5 & Malnourished & 26 & $26 \%$ \\
\hline 6 & Physically Handicapped & 19 & $19 \%$ \\
\hline 7 & Absence of Disease & 11 & $100 \%$ \\
\hline & Total & 100 & 100 \\
\hline
\end{tabular}

According to Table 1, a detailed account on demographic distribution regarding percentage of the beggars as respondents show that out of total street - beggars respondents the dumb beggars were 18 (18\%), the blind 07 (7\%), deaf 15 (15\%), leper 21 (21\%), mentally retarded $17(17 \%)$ and able persons were $22(22 \%)$ respectively. The majority of able bodied beggars (22\%) was pleading in streets to meet both ends meet and on the other side, physical and mental issues forced respondents to find a living through street - begging.

Table 2 provides results about age of the respondents that recorded between 5-6 years to 57 years. Table 3 illustrates a comparative picture of the majority of respondents that belonged to religion Islam $(87 \%)$ while the followers of Christianity were less $(13 \%)$ as compared to the majority of beggars. As presented in Table 4 female respondents were more in ratio (56\%) as compared to the male respondents (44\%) out of the total recorded data.

The study results in Table 5 the data collected through a sample survey, 2019 reveal that most of the respondents were illiterate $83(83 \%)$, primary pass were only $11(11 \%)$ and those who have not completed secondary level education were $6(6 \%)$ respectively. As per Table 6 poverty and street begging found a strong association when the prevalence beggars due to economic factors included unemployment $31(31 \%)$, poverty $44(44 \%)$ at the highest rate among other categories as debt $7(7 \%)$, and lack of employment opportunities were $5(5 \%)$ each mentioned individually. It highlights the fact that due to poverty, street - begging thrive among the respondents of Sialkot city. In the "vicious circle of poverty" generations get struck and for meeting basic needs the poor are supposed to beg as an alternative.

An analysis of Table 7 expose the results regarding social causes of poverty and street - begging which involved a strong factor of orphan hood 31 (31\%) as the utmost prominent reason for beggary, broken family background 8 (8\%), old aging 19 (19\%), lacking caregivers 18 (18\%), influence of peers or friends $13(13 \%)$ and adopting beggary by choice was $11(11 \%)$, each reason presented separately for adopting beggary as a lifestyle. Table 8 depicts the occurrence of ailments among sampled street beggars in Sialkot city show that out of the total $100(100 \%)$, the skin problems faced by the respondents were $17(17 \%)$, asthma 6 (6\%), eye - infection $13(13 \%)$, mental retardation $8(8 \%)$, malnourishment 26 (26\%), physically handicapped 19 (19\%) and absence of disease found among the respondents was $11(11 \%)$ out of total.

The street - beggary in urban localities as a phenomenon has also been influenced by several socio - economic realities that encourage the beggars to ask for alms. Usually, problems connected to street - beggars aren't just related to a single reason or cause. In its place, it is a multifaceted issue which gives spaces to beggars to "end up on the streets." Evidence indicates that though previous 
governments have taken steps i.e. imposing a ban on beggary and discouraging beggars by taking them to welfare homes in the city for reducing the problems of street - begging phenomenon but these efforts were just for the time being.

For fulfillment of basic necessities because of most notably recorded poverty issue, poor people resort to begging as a lifestyle with a minimum chance to escape. Nearly a great chunk of population from study area involved in this occupation as the basic factor was poverty, a sole reason. The poor indulge in begging as a routine matter because absolute poverty forces them. Findings by Tambawal (2010) related to such an understanding also pinpoint the similar results. Moreover, unemployment, insufficient earning, debt and lacking employment opportunities for the population below the poverty line prove to be factors forcing to beg.

The death of a single parent or both was also found to be a serious indicator for young street beggars to find an escape in streets and majority was inclined towards street - begging as an easy option. According to the study, sample population (31\%) of street - beggars proved to be in such a situation due to lack of stable care and maintenance. Furthermore, other notable findings as per the responses on a structured questionnaire included broken family background, old age of senior citizens with lack of any support, absence of caregivers, the influence of peer group as well as the choice of an individual. Such circumstances were found to be the major causes of street - begging. The recognized consequences of beggary were harassment from peer group of beggars, emotional abuse, exposure to severe environmental conditions, accident, various medical problems, etc. were mentioned as vices prevailing in the city.

The study also presents another notable finding that street - beggars suffered from a varying degree of physical disabilities. So, physical disability was found to be a strong reason to depend upon others for meeting basic needs. In Pakistan, as a developing nation physically disabled persons face many problems even in their everyday functioning. Finding an economic earning becomes quite challenging for the disabled. With regard to their disability, beggars earn a living by asking others. Thus, the disabled persons find it greatly difficult to earn money and usually the environment is unfriendly as well as unsuitable for themselves.

\section{Recommendations}

By considering the topic under study, some proposed solutions can address the general poverty problem as well as street - begging issue along the axis. For making the beggar community's conditions better and leaving this lifestyle:

- The marginalization from social life and work count to be the critical and bitter and realities under which street - beggars manage a living. Thus, the right to maintenance and availability of basic needs are known as preliminary building blocks before Pakistani urban localities to tackle poverty and street - begging.

- Formation of rational policies in uprooting the menace of street - begging.

- Provision of capital for starting small business and its availability on easy terms conditions.

- Availability of accommodation and shelter homes with income generation facilities.

- Easy access to care homes working under social welfare services.

- Coordinated efforts of government departments and civil society organizations for actual implementation of law. 


\section{References}

Adedibu, A. A., \& Jelili, M. O. (2011). Package for controlling street begging and rehabilitating beggars and the physically challenged in Nigeria: Paper for policy consideration. Global Journal of Human-Social Science Research, 11(1).

Bukoye, R. O. (2015). Case study: Prevalence and consequencies of streets begging among adults and children in Nigeria, Suleja Metropolis. Procedia-Social and Behavioral Sciences, 171, 323-333.

Demewozu, W. (2005). Begging as a means of livelihood: conferring with the poor at the orthodox religious ceremonial days in Addis Ababa 29: 185-191.

Frederick, M. A. J., Joseph, S. T., Srivastava, H., Frederick, A., Joseph, D., \& Srivastava, H. Begging in India: Barricading the Sustainable Financial Development. Social Sciences, 3(03), 2016.

Hamidreza Khazaeifar, Saeed Sardashti Birjandi, Ali Heydari Nia, Fatemeh Khazaeifar, Studying Beggary of Children and Adolescents in Zahedan City and Its Prevention Strategies. Adv. Environ. Biol., 9(2), 981-987, 2015.

Jelili, M. O. (2013). Street-Begging in Cities: Cultural, Political and Socio-Economic Questions. Global Journal of Human-Social Science Research.

Olawale, S. G. (2007). Aetilological perception of alms-begging behaviours among people with special needs in Oyo State: Counselling Towards Solution. The Counsellor, 23(1), 44-53.

Ottaway M (1975) (ed.) Urbanization in Ethiopia: A Text with Readings in Urban Sociology, A.A.U, Unpublished.

Tambawal, M. U. (2010, June). The effects of street begging on the national development: counselling implications. In 1st National Conference of the Counselling Association of Nigeria (CASSON) Katsina State. 